\title{
SMOOTH SNAKE CORONELLA AUSTRIACA (SERPENTES: COLUBRIDAE), A NEW SPECIES FOR THE OPHIDIOFAUNA IN THE ORENBURG STATE NATURE RESERVE (RUSSIA)
}

\author{
Andrey G. Bakiev', Olga G. Kalmykova², Roman A. Gorelov ${ }^{1}$ \\ ${ }^{1}$ Institute of Ecology of the Volga River Basin of RAS, Russia \\ e-mail:herpetology@list.ru \\ ${ }^{2}$ Institute of Steppe, Ural Branch of RAS, Russia \\ e-mail: o.k.81@list.ru
}

Received: 29.03.2018

\begin{abstract}
A report on the discovery of the smooth snake Coronella austriaca in the cluster area «Aytuarskaya steppe» of the Orenburg State Nature Reserve (Russia, Orenburg region, Kuvandykskiy district) on the 24 July 2017 is given. This is the first recording of the species for the Orenburg region on the left bank of the River Ural. The specimen was a pregnant female in molting state. The capture location $\left(51^{\circ} 06.161^{\prime} \mathrm{N}, 57^{\circ} 41.853^{\prime} \mathrm{E}, 279 \mathrm{~m}\right.$ a.s.1.) is at the top of a ridge with outcrops of bedrock occupied by rarefied petrophytic steppe plant communities. Among other reptiles inhabiting the location, only the lizard Lacerta agilis was registered, which is, presumably, the most frequent prey for the smooth snake.
\end{abstract}

Key words: Aytuarskaya steppe, habitat, new location, Orenburg region, Protected Area

The first record of the smooth snake Coronella austriaca within the current borders of the Orenburg region (one specimen, in the Karavaevskaya grove near Orenburg) was published by Zarudny (1896), who attributed the smooth snake to the extremely rare animals of the Orenburg region. In the late $20^{\text {th }}$ century, the total number of this species in the Orenburg region approximately did not exceed 100-150 individuals (Chibilev, 1998). The species is included in the regional Red Data Book with the rarity status 3 (Decree of the Government, 2014). In the Ural, the smooth snake has the status of a rare, small-numbered and possibly endangered species (Vershinin, 2007).

According to previous studies (Chibilev, 1995, 1999, 2014) the Orenburg State Nature Reserve is inhabited by four species of snakes: the grass snake Natrix natrix (Linnaeus 1758), diced snake Natrix tessellata (Laurenti 1768), Dione snake Elaphe dione (Pallas 1773), and the eastern steppe viper, also known as the Renard's viper Vipera renardi (Christoph 1861). The results of our research in 2017 have allowed us to supplement the ophidiofauna of the reserve with the smooth snake, Coronella austriaca (Laurenti 1768). This species is listed in the IUCN Red List (Crnobrnja Isailovic et al., 2009) under the Least Concern category, in Appendix II «Strictly protected fauna species» of the Bern Convention (Convention, 1979), threatened and/or protected in many countries (e.g., Santos et al., 2009; Jelić, 2010; Galarza et al., 2015; Sztencel-Jabłonka et al., 2015).
On the 24 July 2017, at 4:50 p.m., a pregnant molting female smooth snake was found in the cluster area «Aytuarskaya steppe» of the Orenburg State Nature Reserve (Russia, Orenburg region, Kuvandykskiy district) (Fig. 1, 2).

«Aytuarskaya steppe», being the most mountainous area of the Orenburg State Nature Reserve and an analogue of the Huberlin Mountains, belongs to the riverside low hills. Almost the whole territory of this district is a system of deep mountain valleys laid mainly from south to north along a strike of folding and rock strata. The exceptions include the northernmost near-floodplain part of the River Ural and the Alimbet Plateau in the south. Most inter-valley watersheds of the area have the form of ridges complicated by saddles. These crests are composed of either conglomerates and breccias, or limestones (Chibilev, 1996).

The capture site of the smooth snake $\left(51^{\circ} 06.161^{\prime} \mathrm{N}, 57^{\circ} 41.853^{\prime} \mathrm{E}, 279 \mathrm{~m}\right.$ a.s.l.) is located at the inter-valleys watershed of the Zharyk and Sartkaragashta valleys. This is a ridge characterised by incompletely developed soils and their complexes with outcrops of bedrock on the tops and upper parts of the slopes.

The snake was captured at the top of a ridge occupied by rarefied petrophytic steppe plant communities with the presence of petrophytic forbs (e.g. Scorzonera austriaca Willd., Potentilla arenaria Borkh., Oxytropis floribunda (Pall.) DC.), grasses (Elytrigia pruinifera Nevski) and dwarf 
subshrubs (Artemisia salsoloides Willd., Astragalus helmii Fisch.).

At the middle part of the slopes, following plant species were found: with the predomination of Stipa zalesskii Wilensky, significant participation of petrophytic species among the forbs, and sometimes with Artemisia marschalliana Spreng., A. salsoloides and shrubs (Spiraea hypericifolia L.) (Fig. 3).

The weight of the snake is $76.2 \mathrm{~g}$, the length of the trunk with the head (L. corp.) $520 \mathrm{~mm}$, the length of the tail $(L . c d$.) $107 \mathrm{~mm}$, the number of scales around the middle of the trunk $(S q$.) 19, the number of ventral shields (Ventr.) 183, anal shield (A.) divided - 1/1, number of subcaudal shields $(S c d$.) -
51 pairs, number of upper labial shields (Lab.) to the right -7 , left -7 , number of temporal shields (Temp.) in the first and second rows to the right $-2+2$, on the left $-2+3$. The upper part of the body with a slightly noticeable characteristic pattern is painted in grayish-brown tones, the lower part in gray.

On the next day, $25^{\text {th }}$ July, the smooth snake completed molting and was released at the place of capture. Among other reptiles inhabiting the location, only the lizards Lacerta agilis (Linnaeus 1758) were registered. Presumably, this species as well as other reptiles are the most frequent prey for the smooth snake, similarly to data of other authors (Spellerberg \& Phelps, 1977; Luiselli et al., 1996; Drobenkov, 2000).

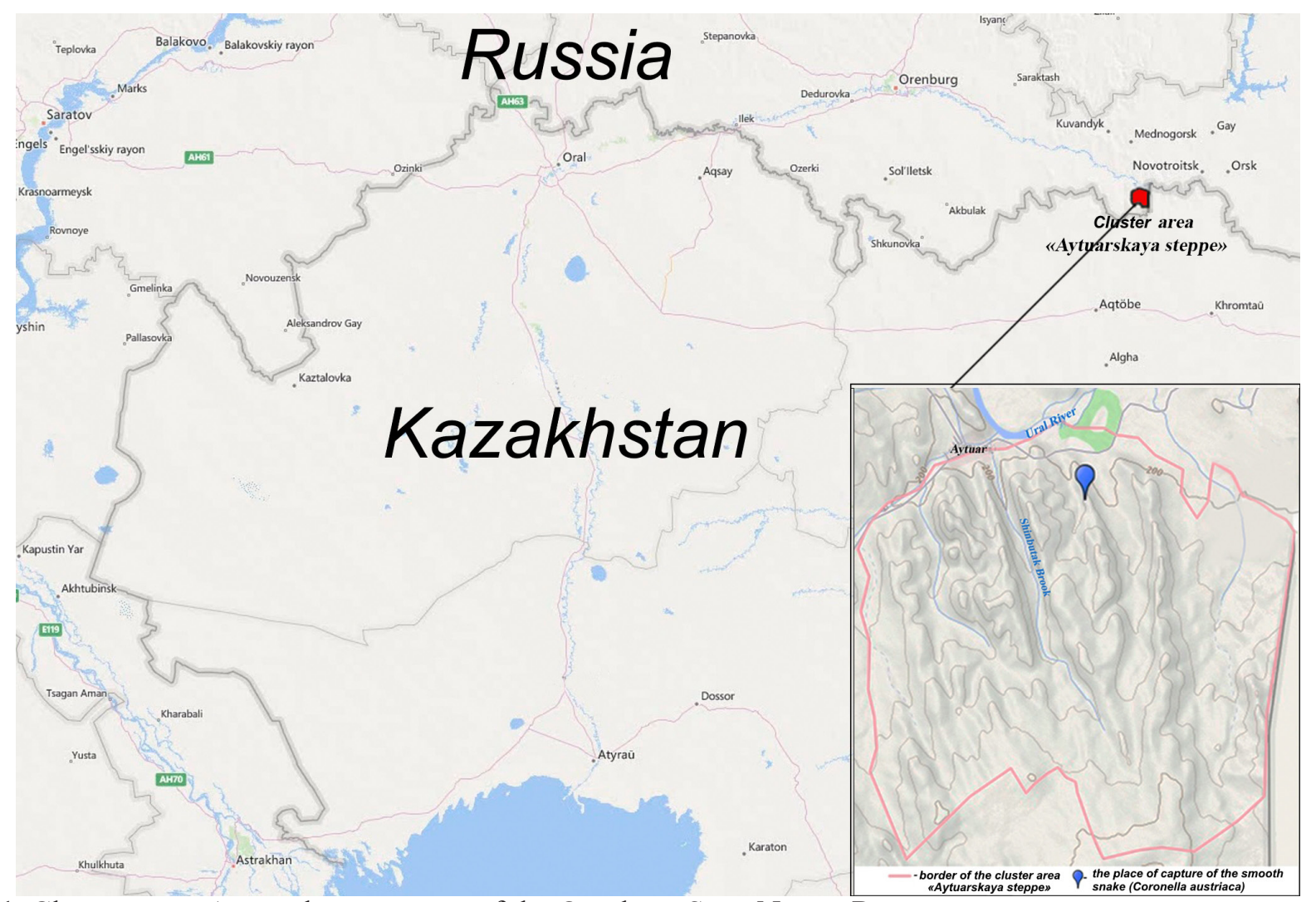

Fig. 1. Cluster area «Aytuarskaya steppe» of the Orenburg State Nature Reserve.

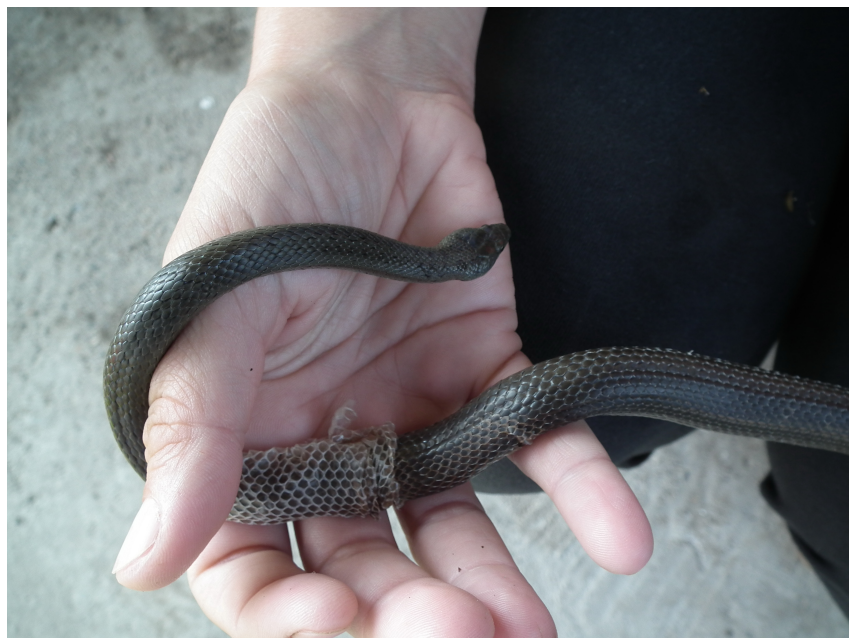

Fig. 2. Captured smooth snake (in a molting state).

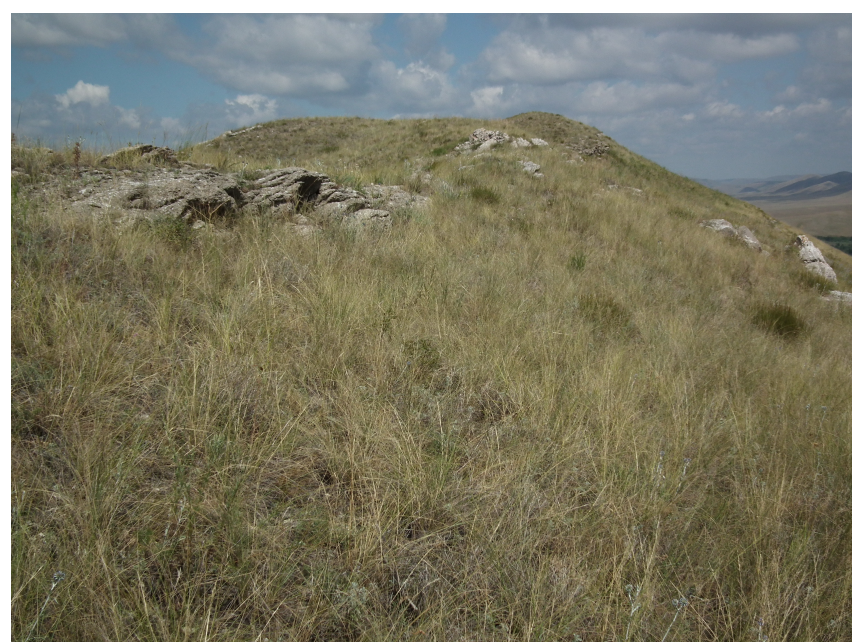

Fig. 3. The habitat of the smooth snake. 
The capture point is located at the southeastern periphery of the area (Bannikov et al., 1977; Debelo \& Chibilev, 2013). In Russia, this is the closest point to the few locations of the species in Kazakhstan (Paraskiv, 1956; Dubrovsky, 1967). Comparing with the other records of the smooth snake in the Orenburg region (Zarudny, 1896; Lindholm, 1902; Polozhentsev, 1935; Rajsky, 1951; Darkshevich, 1953; Chibilev, 1995, 1998; Bakiev et al., 1996) the current place of capture can be characterised as the most eastern, if considering only the left bank of the Ural within contemporary borders of the region as unique. According to local inhabitants, this «green snake» can be encountered in the vicinity of the protected area «Aytuarskaya steppe». Apparently, it is a smooth snake of a green morpha, known from the Kargalinskaya steppe (Lindholm, 1902) and the Trans-Urals (Vershinin, 2007).

\section{References}

Bakiev A.G., Barinov V.G., Peskov A.N., Gorelova L.S., Krendelev V.V., Maleniev A.L. 1996. Compilation of a species list of reptiles of the Buzulukiy pine forest and the Krasnosamarskiy forest. In: Actual problems of herpetology and toxinology. Vol. 2. Togliatti. P. 73-74. [In Russian]

Bannikov A.G., Darevsky I.S., Ishchenko V.G., Rustamov A.K., Shcherbak N.N. 1977. Determinant of amphibians and reptilesof the USSR fauna. Moscow: Prosveshchenie. 414 p. [In Russian]

Chibilev A.A. 1995. Amphibians and reptiles of the Orenburg region and their protection: Materials for the Red Data Book of the Orenburg region. Ekaterinburg: UB RAS. 46 p. [In Russian]

Chibilev A.A. (Ed.). 1996. Steppe Orenburg Reserve: geographical and ecological characteristics. Ekaterinburg: UB RAS. 167 p. [In Russian]

Chibilev A.A. 1998. The smooth snake. In: Red Data Book of the Orenburg region. Orenburg: Orenburg Publishing house. P. 81. [In Russian]

Chibilev A.A. 1999. Herpetofauna of the Orenburg State Reserve. In: Second Conference of herpetologists of the Volga region: Book of abstracts. Togliatti. P. 55-56. [In Russian]

Chibilev A.A. 2014. Orenburg Reserve: the history of creation and natural diversity. Ekaterinburg: LLC «UIPTs». 139 p. [In Russian]

Convention on the Conservation of European Wildlife and Natural Habitats. Bern, 1979. Available from http:// www.coe.int/en/web/conventions/full-list/-/conventions/treaty/104 (Retrieved: 22.03.2018). [In Russian]

Crnobrnja Isailovic J., Ajtic R., Vogrin M., Corti C., Mellado V.P., Sá-Sousa P., Cheylan M., Pleguezuelos J., Westerström A., De Haan C.C., Tok V., Borczyk B., Sterijovski B., Schmidt B. 2009. Coronella austriaca. In: The IUCN Red List of Threatened Species 2009: e.T157284A5070002. Available from: http://www.iucnredlist.org/details/157284/1 (Retrieved: 09.05.2018).

Darkshevich Ya. 1953. Buzuluksky pine forest: (Popular-scientific monograph). Chkalov: Chkalovsk Book Publishing House. 88 p. [In Russian]
Debelo P.V., Chibilev A.A. 2013. Amphibians and reptiles of the Ural-Caspian region. Ekaterinburg: UB RAS. 400 p. [In Russian]

Decree of the Government of Orenburg region of April 16, 2014 No. 229-p «On Amendments to the Orenburg region Government Decree of January 26, 2012 No. 67-p». Available from http://oopt.aari.ru/ sites/default/files/documents/pravitelstvo-Orenburgskoy-oblasti/N229-p_16-04-2014.pdf (Retrieved: 22.03.2018). [In Russian]

Drobenkov S.M. 2000. Ecology of Smooth Snake (Coronella austriaca Laur.) in Belarus. Russian Journal of Herpetology 7(2): 135-138.

Dubrovsky Yu.A. 1967. New records of reptiles in the steppes of Kazakhstan. Bulletin of Moscow Society of Naturalists 72(1): 146-147. [In Russian]

Galarza J.A., Mappes J., Valkonen J.K. 2015. Biogeography of the smooth snake (Coronella austriaca): origin and conservation of the northernmost population. Biological Journal of the Linnean Society 114(2): 426-435. DOI: $10.1111 /$ bij. 12424

Jelić D. 2010. Record of Coronella austriaca (Laurenti, 1768) from the Island of Mljet, southern Croatia. Herpetozoa 23(1/2): 85-87.

Lindholm W.A. 1902. Beiträge zur Biologie einiger Reptilien des Europäischen Russlands. Der Zoologische Garten 43 (1/2): 20-26, 41-56.

Luiselli L., Capula M., Shine R. 1996. Reproductive output, cost of reproduction, and ecology of the smooth snake, Coronella austriaca, in the eastern Italian Alps. Oecologia 106(1): 100-110. DOI: 10.1007/BF00334412

Paraskiv K.P. 1956. Reptiles of Kazakhstan. Alma-Ata: Publishing House of the Academy of Sciences of the Kazakh SSR. 228 p. [In Russian]

Polozhentsev P.A. 1935. Towards the fauna of mammals and reptiles of the Buzulukskiy pine forest. In: Materials on the study of the nature of the Middle Volga region. Vol. 1. Moscow; Kuybyshev: Kuybyshev Regional Publishing House. P. 77-96. [In Russian]

Rajsky A.P. 1951. Fauna of Chkalovsky area. In: Sketches of physical geography of Chkalovsky area. Chkalov. P. 157-202. [In Russian]

Santos X., Caro J., Abril A.J., Lorenzo M., Brito J.C., Pleguezuelos J.M. 2009. Habitat suitability, threats and conservation of isolated populations of the smooth snake (Coronella austri$a c a)$ in the southern Iberian Peninsula. Biological Conservation 142(2): 344-352. DOI: 10.1016/j.biocon.2008.10.030

Spellerberg I.F., Phelps T.E. 1977. Biology, general ecology and behaviour of the snake, Coronella austriaca Laurenti. Biological Journal of the Linnean Society 9(4): 133-164. DOI: 10.1111/j.1095-8312.1977.tb00263.x

Sztencel-Jabłonka A., Mazgajski T.D., Bury S., Najbar B., Rybacki M., Bogdanowicz W., Mazgajska J. 2015. Smooth Snake Phylogeography and Population Structure. Biological Journal of the Linnean Society 115(1): 195-210. DOI: 10.1111/bij.12496

Vershinin V.L. 2007. Amphibians and reptiles of the Ural. Ekaterinburg: UB RAS. 171 p. [In Russian]

Zarudny N. 1896. Materials for fauna of amphibians and reptiles of the Orenburg region. Bulletin Société Impériale des Naturalistes de Moscou. Nov. Série 9(3): 361-370. [In Russian] 
ОБЫКНОВЕННАЯ МЕДЯНКА CORONELLA AUSTRIACA (SERPENTES: COLUBRIDAE) - НОВЫЙ ВИД В ОФИДИОФАУНЕ ГОСУДАРСТВЕННОГО ПРИРОДНОГО ЗАПОВЕДНИКА «ОРЕНБУРГСКИЙ» (РОССИЯ)

\author{
А. Г. Бакиев ${ }^{1}$ О. Г. Калмыкова ${ }^{2}$ Р. А. Горелов ${ }^{1}$ \\ ${ }^{1}$ Институт экологии Волжсккого бассейна РАН, Россия \\ e-mail: herpetology@list.ru \\ ${ }^{2}$ Институт степи УрО РАН, Россия \\ e-mail: o.k.81@list.ru
}

\begin{abstract}
Приведены сведения о находке обыкновенной медянки Coronella austriaca на участке «Айтуарская степь» заповедника «Оренбургский» (Россия, Оренбургская область, Кувандыкский район) 24 июля 2017 г. Это первая для Оренбургской области находка вида из Левобережья Урала. Беременная самка находилась в

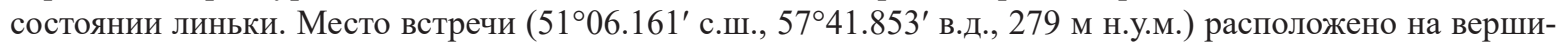
не хребта с выходом коренных пород, занятой разреженными петрофитностепными растительными сообществами. Из других пресмыкающихся в биотопе встречены только прыткие ящерицы Lacerta agilis, которые относятся к основным объектам питания обыкновенной медянки.
\end{abstract}

Ключевые слова: Айтуарская степь, местообитание, новое местонахождение, ООПТ, Оренбургская область 